\title{
GENDER INEQUITY IN UTILISATION OF PUBLICLY FUNDED HEALTH INSURANCE SCHEMES: FINDINGS BASED ON INSURANCE DATA FROM A SOUTHERN INDIAN STATE
}

\author{
---Is there a difference in utilisation of state sponsored health \\ insurance between men and women?
}

Rajalakshmi RamPrakash, Joe Arun

Loyola Institute of Business Administration, Loyola College, Chennai, India

Correspondence: Rajalakshmi.r@liba.edu

\begin{abstract}
While Publicly Funded Health Insurance Schemes (PFHIS) can be an effective strategy to achieve Universal Health Coverage by offering financial protection, the extent to which they facilitate gender equity has been less explored. Women constitute one of the main vulnerable groups owing to a combination of health and economic vulnerabilities to access inpatient care services. Gender health equity requires that healthcare resources, such as PFHIS effectively reach women. This study investigates the gender differences in utilisation of Chief Ministers' Comprehensive Health Insurance Scheme (CMCHIS) by looking at a large volume of claims data covering 2012 to 2014 in the southern Indian state, Tamil Nadu. Previous studies indicate that women in the state had a higher hospitalisation rate than men and are entitled equally to CMCHIS.
\end{abstract}

By disaggregating the data on number of beneficiaries, claim status, average and total claim value, type of procedures based on gender on a random selection of 230265 cases, the paper points out that women's utilization of CMCHIS is significantly lesser than men. Women constitute only $36 \%$ of all beneficiaries and received only half of the total claim value disbursed through the scheme. This pro-male bias was found to be statistically significant and consistent across the scheme years, age group and type of procedures. The study concludes that the gender inequity in utilization of CMCHIS is conspicuous and needs immediate attention from policy makers and administrators. With recent inclusion of COVIDI9 testing and treatment under PFHIS, the paper urges for further research lest more women are left behind.

\section{KEYWORDS}

Gender difference, PHFIS, claims, gender equity, CMCHIS, India

\section{INTRODUCTION}

There is an impetus across lower middle-income countries like India to introduce new health insurance schemes to different target groups in order to increase the access to medical treatments and achieve Universal Health Coverage (UHC). UHC is closely tied to the concept of health equity .[1] For achieving health equity, healthcare 
resources should be allocated similarly to all those with similar need (horizontal equity) and differentially to those with different needs (vertical equity). [2]Women's health needs are both similar and different to that of men. Gender health equity is achieved only when both horizontal (such as diabetes) and vertical equity (such as sexual and reproductive health issues) concerns are acknowledged and addressed.

Several studies in India that have found gender based differences in allocation of healthcare resources within the household [3-6].This has resulted in poor access to healthcare services for women and resulting in higher morbidity and mortality. In this context, health financing through publicly funded health insurance schemes (PFHIS) can serve as an excellent strategy to help women to increase access to healthcare. PFHIS targeted at the poor and informal population ensure financial protection by eliminating or limiting catastrophic health expenditures. Since 2007, India has had several state sponsored health insurance schemes such as Rajiv Arogya Sri, Rashtriya Swasthya Bima Yojana (RSBY), etc. culminating in 2018 as the Pradhan Mantri Jan Arogya Yojana (PMJAY) or National Health Protection Scheme. Due to the health and financial crisis created by COVID19 pandemic, in April 2020, Government of India announced that COVID19 testing and treatment would be covered under the PMJAY.

However not much is known on how much these health insurance schemes has facilitated women to utilize inpatient care. Literature on PFHIS consider insurance claims approved as a proxy for utilisation by beneficiaries. Utilization estimates assessed through claims data mostly indicated a pro-male bias in two states in India. [7-9] Primary studies have also found gender differences in utilisation of PFHIS favouring the male. [10-12] Occasionally some studies found a bias favouring women. [13,14] Studies that used the National Sample Survey Organisation (NSSO) by the Government of India also found gender differences in PFHIS utilization in India. [15] A recent systematic review [16] indicates this could just be the tip of the iceberg as often PFHIS studies base their findings on households as a single unit thereby neglecting to explore intrahousehold dynamics and vertical equity. As a result of the absence of a gender lens in PFHIS studies, gender equity continues to remain an under researched subject.
Given that a large share of the health budget is allocated to PFHIS within the country's limited fiscal space, there is a research gap on the whether they facilitate access to inpatient care for women. To fill up this crucial research gap, the current paper looks at one of the most developed states in India, Tamil Nadu (TN), where the development indicators such as sex ratio, female literacy, etc are higher than the national average. Unlike schemes like RSBY, all members of the household irrespective of sex are covered under the Chief Minister's Comprehensive Health Insurance Scheme (hence forth CMCHIS) [17] According to the National Sample Survey $71^{\text {st }}$ round data, women in Tamil Nadu have a higher hospitalization rate $(6.8 \%)$ than men (4.6\%) [18], which meant that there is likely to be an equal if not higher utilization of CMCHIS by women in this state.

This paper seeks to find out gender differences in utilization of the scheme by analysing the insurance claims data of CMCHIS. The patterns in utilization are evaluated against what is expected from policy to meet the financial health protection needs of women.

\section{METHODS}

The administrative data was procured through a formal application by the first author as a part of her doctoral study to the implementing government agency. The data on insurance claims made under the $\mathrm{CMCHIS}$ was obtained from the Third-party Administrator (TPA) of the insurance company. Claims between January 2012 to December $31^{\text {st }} 2014$, totalling 924372 was obtained as a dump in Microsoft Excel format, which had to be cleaned and exported to SPSS for analyses.

Since the sample size was huge, for convenience a random sample consisting of $25 \%$ of the overall sample was drawn using the "select cases' function of SPSS v21. This yielded a total of 230265 cases which were then used for further analysis. Some dummy variables were created to facilitate analysis. Table 1 gives a brief of all variables.

Basic descriptive statistics was performed to explore the patterns in number of beneficiaries, age of beneficiaries, insurance claim amount (average and total), types of procedures and specialty, etc across gender. The significance of differences in key variables were computed using t-test and Chi square methods of analyses. 
TABLE 1: TYPES OF VARIABLES USED IN STUDY

\begin{tabular}{|l|l|l|}
\hline Name of Variable & Type & Explanation \\
\hline Gender of Patient & Categorical \& Independent & $\begin{array}{l}\text { Male was assigned as 1 and } \\
\text { Female as 2 }\end{array}$ \\
\hline Total Claim Value & Continuous \& Dependent & $\begin{array}{l}\text { The mean value of all claims } \\
\text { approved expressed as INR }\end{array}$ \\
\hline Type of Procedure & Continuous \& Dependent & $\begin{array}{l}\text { The sum of all approved claim } \\
\text { values }\end{array}$ \\
\hline Status of Claim & Categorical \& Independent & $\begin{array}{l}\text { Follow-up procedures assigned } \\
\text { as 1, Surgical procedures as 2 } \\
\text { and Medical procedures as 3 }\end{array}$ \\
\hline Specialty & Categorical \& Dependent & $\begin{array}{l}\text { A total of 9 categories recoded } \\
\text { to a dummy with 3 categories- } \\
\text { Approved, Denied and Query } \\
\text { (In process) }\end{array}$ \\
\hline
\end{tabular}

\section{RESULTS}

Results have been categorized broadly under the following sections:
A. Gender differences in CMCHIS Utilization
B. Gender differences in CMCHIS Claim Status
C. Gender differences in Average Claimed Value, Final Approved Value and Total Claim Value
D. Gender Differences in Type of Procedure
E. Gender Differences in Specialty

\section{A) GENDER DIFFERENCES IN CMCHIS UTILIZATION}

As shown in Figure 1, overall, men constituted $63.67 \%$ of all beneficiaries who made claims under the CMCHIS in Tamil Nadu over the three years.

A more concerning pattern as seen in Figure 2 is that though utilization of CMCHIS was improving year by year, the share of women in overall utilization of $\mathrm{CMCHIS}$ was decreasing from 2012 to 2013 and further in 2014. The gender difference was found to be statistically significant (Table 6 in Annexures).

FIGURE1: GENDER DIFFERENCES AMONG BENEFICIARIES OF CMCHIS 2012-14

\section{GENDER DIFFERENCES IN CMCHIS BENEFICIARIES_2012 TO 2014 \\ - Male $\mathbf{a}$ Female}

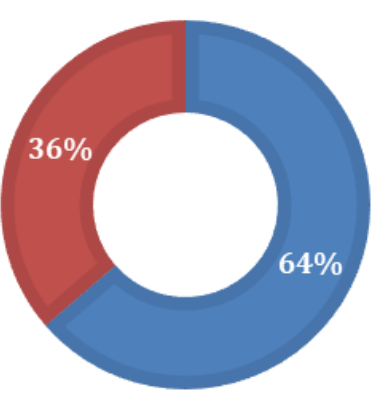




\section{Gender Differences in CMCHIS Utilisation}

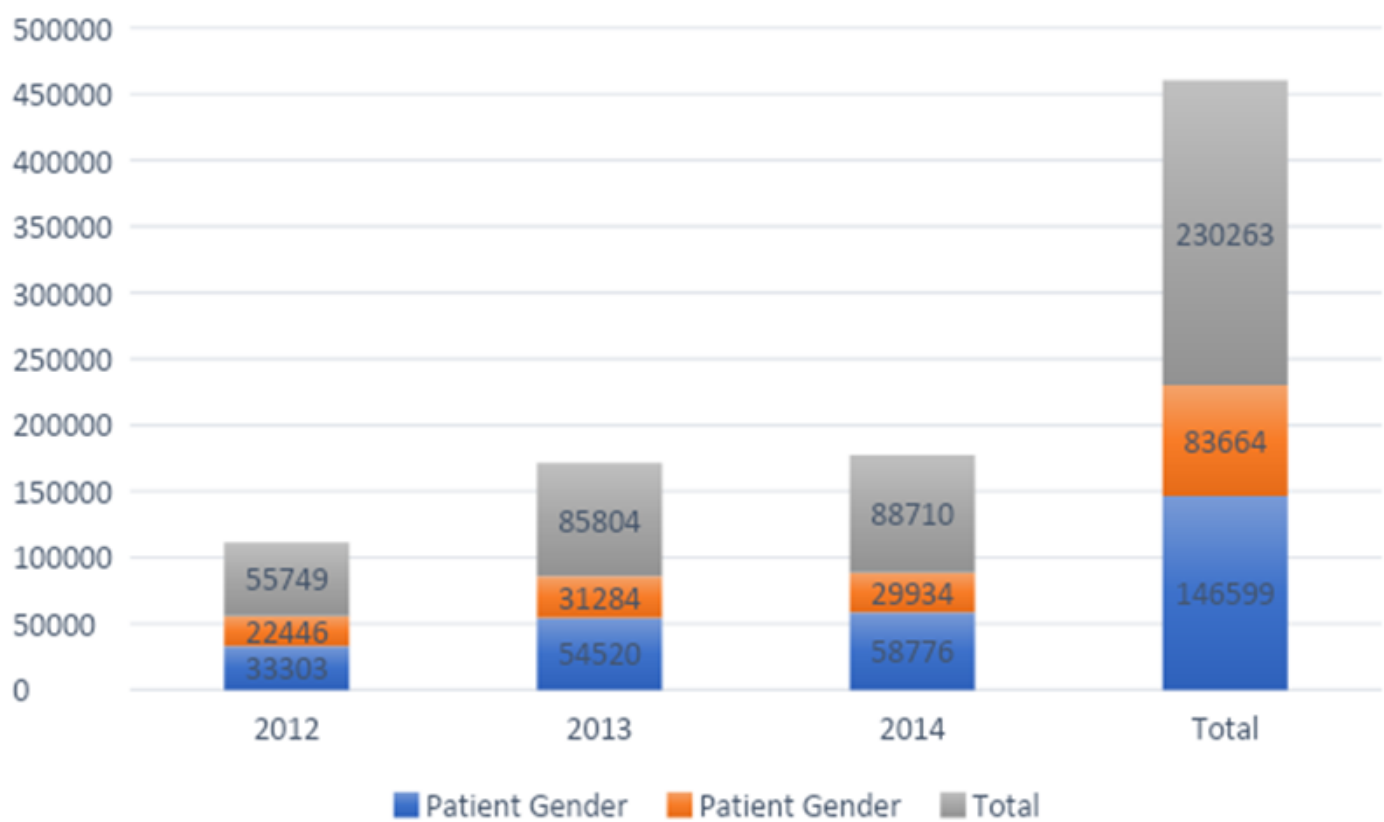

\section{A. GENDER DIFFERENCES IN CMCHIS CLAIM STATUS}

When a preauthorisation request is sent from the empanelled healthcare facility to the insurance company along with supporting documents, a decision is taken by the concerned TPA on whether or not the pre-authorisation can be approved. Based on the data shared by the TPA, the decisions by the insurance claims department have been classified under three heads as:

(1) Approved

(2) Denied

(3) In Query (In process, where final decision not yet taken)

Table 2 shows that for the years 2012 to 2014, for every year, TABLE 2: CLAIM STATUS IN CMCHIS BY GENDER_2012-14

\begin{tabular}{|l|l|l|l|}
\hline & $\begin{array}{l}\text { PATIENT } \\
\text { GENDER }\end{array}$ & TOTAL \\
\hline & Male & Female & \\
\hline APPROVED & 145150 & 82868 & 228018 \\
\hline & $\mathbf{6 3 . 7 0 \%}$ & $\mathbf{3 6 . 3 0 \%}$ & $100.00 \%$ \\
\hline DENIED & 815 & 512 & 1327 \\
\hline QUERY & $61.40 \%$ & $\mathbf{3 8 . 6 0 \%}$ & $100.00 \%$ \\
\hline & 636 & 284 & 920 \\
\hline TOTAL & $\mathbf{6 9 . 1 0 \%}$ & $\mathbf{3 0 . 9 0 \%}$ & $100.00 \%$ \\
\hline & $63.70 \%$ & $36.30 \%$ & $100.00 \%$ \\
\hline
\end{tabular}
almost $99 \%$ of all preauthorised claims were approved. The number of male beneficiaries were higher than the female in all the three categories, the largest gap being in the cases that were in query. The study found that there is a statistically significant relationship between status of claim and gender. (See Table 7 in Annexure)

\section{B. GENDER DIFFERENCES IN AVERAGE CLAIMED AND AVERAGE APPROVED AMOUNT}

Each treatment procedure included under the CMCHIS is pre-fixed for a specific reimbursement rate by the scheme administration agency. [17] When a preauthorisation request is made, usually the empanelled facility requests for the package rate or even occasionally higher depending on the other conditions of the patient. The TPA scrutinises 
the merit of the case with the documents submitted and uses the discretionary power to finally award an amount that can be equal or lesser to the claimed amount.

Table 3 indicates that the average (or per capita) of the approved claim amount for males was INR 11132.82 while it was INR 9714.37 for females. Similarly the final approved amount is higher for males compared to female (INR 20546.63 versus INR 19097.1). This difference was found to be statistically different at a $99 \%$ confidence interval. (Table 8 in Annexures).

The total claim value of all reimbursed amounts put together in the scheme over the years showed that the male share of claims was almost double of that of women as represented in Figure 3. (INR 298,96,36,855 for males versus INR 158,72,36,232 for females).
FIGURE 3 TOTAL CLAIM AMOUNT IN CMCHIS 2012-14

Total Claim Amount (in crores) in CMCHIS 2012-14

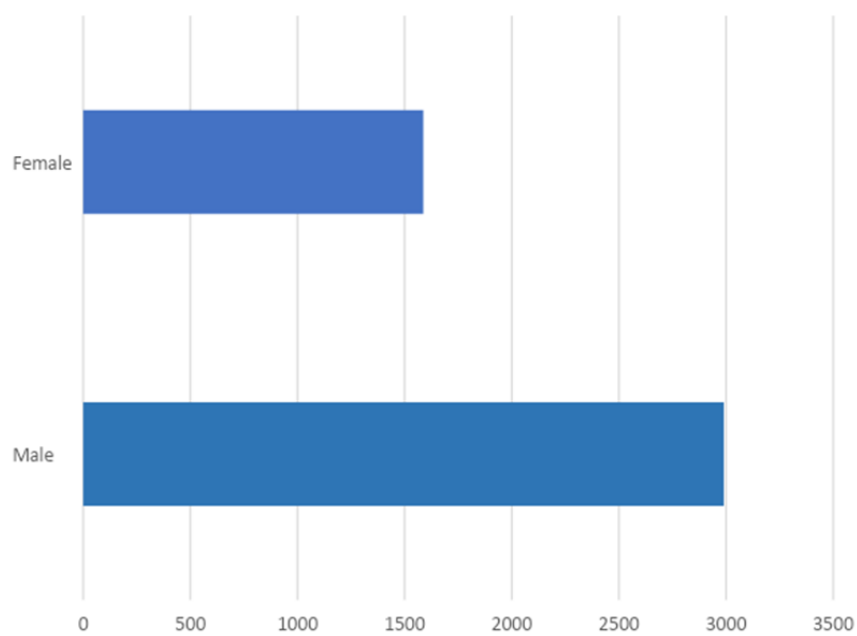

TABLE 3: GENDER DIFFERENCES IN CLAIMED AND FINAL APPROVED VALUE IN CMCHIS_2012 TO 14

\begin{tabular}{|l|l|l|l|l|l|}
\hline & $\begin{array}{l}\text { PATIENT } \\
\text { GENDER }\end{array}$ & N & MEAN & $\begin{array}{l}\text { STD. } \\
\text { DEVIATIO } \\
\text { N }\end{array}$ & $\begin{array}{l}\text { STD. } \\
\text { ERROR } \\
\text { MEAN }\end{array}$ \\
\hline Claimed Amount in INR & Male & 146601 & 11132.82 & 18443.7 & 48.17 \\
\hline & Female & 83663 & 9714.37 & 17056.6 & 58.969 \\
\hline $\begin{array}{l}\text { Final Approved Amount } \\
\text { in INR }\end{array}$ & Male & 145505 & 20546.63 & 22341.1 & 58.569 \\
\hline & Female & 83114 & 19097.1 & 21250.2 & 73.71 \\
\hline
\end{tabular}

\section{GENDER DIFFERENCES IN TYPE OF PROCEDURES}

The CMCHIS covers a total of 1016 procedures divided into Medical, Surgical and Follow up procedures. The study attempted to find if gender differences within each type of procedure exists.

Figure 4 shows that in general, utilization of Follow up procedures was far less in CMCHIS compared to Medical and Surgical. A sex disaggregated analysis shows that while claims from males dominate all three types of procedures, the gap between the sexes is starker in medical procedures.
FIGURE 4 GENDER DIFFERENCES IN CMCHIS PROCEDURES 2012 TO 2014

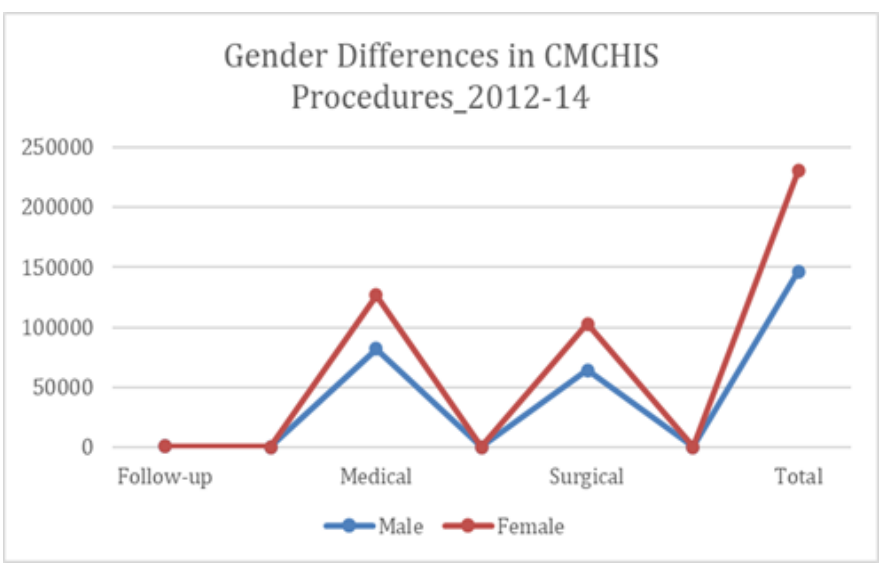

1 Conversion rate in May 2021 stands at 1 INR $=0.014$ United States Dollar 
The study found that these gender differences across specialty were statistically significant. (Table 9 in Annexure)

The average approved claim amount for Surgical, Medical and Follow-up procedures were calculated and given in Table 4. The mean of Surgical procedures was the highest at INR 30939.05 while medical procedures was INR 11258.21 and the lowest was for the follow up procedures.

\section{GENDER DIFFERENCES IN SPECIALTY}

The gender differences across the 34 specialty ${ }^{2}$ as represented in Figure 5 reveals that in most men overtake women, especially in Nephrology, Genito Urinary surgery, ENT, cardio thoracic surgeries, orthopaedic surgeries, etc. The only specialties where women overtake men were medical oncology, radiation oncology, surgical oncology and gynaecology/obstetrics

TABLE 4: AVERAGE CLAIM AMOUNT FOR DIFFERENT PROCEDURES IN CMCHIS 2012-2014

\begin{tabular}{|l|l|l|l|}
\hline \multicolumn{4}{|c|}{ AVERAGE CLAIM AMOUNT (IN INR) OF PROCEDURES IN INR } \\
\hline & Surgical & Medical & Follow up \\
\hline Mean & 30939.05 & 11258.21 & 1791.21 \\
\hline Median & 20000 & 8000 & 1000 \\
\hline
\end{tabular}

FIGURE 5 GENDER DIFFERENCES ACROSS SPECIALTY IN CMCHIS 2012-2014

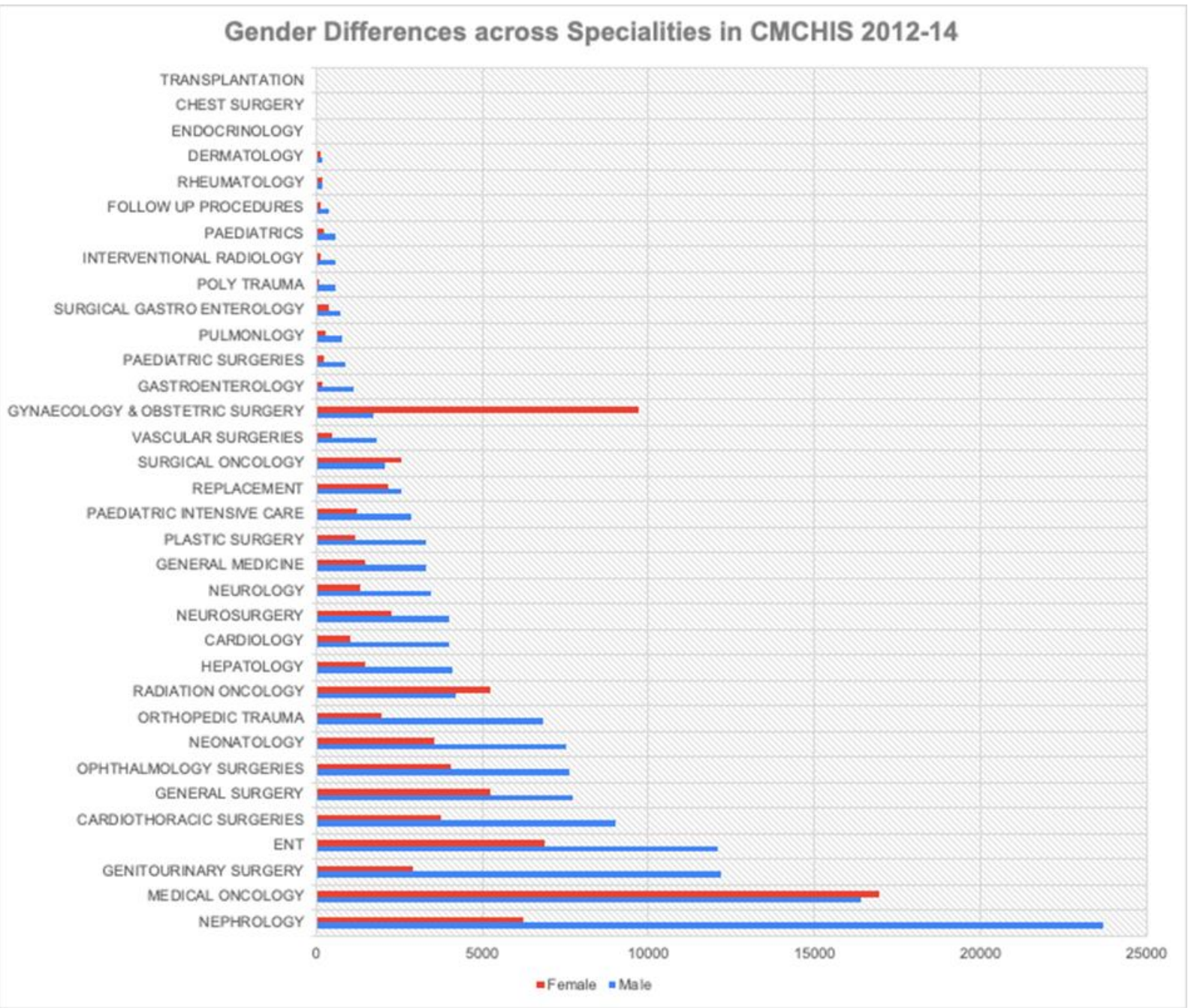

${ }^{2} \mathrm{CMCHIS}$ does not cover pregnancy and childbirth 


\begin{tabular}{|l|l|l|l|l|l|l|}
\hline MALE & $\begin{array}{l}\text { AVERAGE } \\
\text { CLAIM } \\
\text { AMOUNT } \\
\text { IN INR }\end{array}$ & $\begin{array}{l}\text { \% OF } \\
\text { ALL } \\
\text { MALE } \\
\text { CLAIMS }\end{array}$ & FEMALE & $\begin{array}{l}\text { AVERAGE } \\
\text { CLAIM } \\
\text { AMOUNT IN } \\
\text { INR }\end{array}$ & $\begin{array}{l}\text { \% OF } \\
\text { ALL } \\
\text { FEALE } \\
\text { CLAIMS }\end{array}$ \\
\hline 1 & Nephrology & 8320.72 & 16.2 & $\begin{array}{l}\text { Medical } \\
\text { oncology }\end{array}$ & 5793.60 & 20.3 \\
\hline 2 & $\begin{array}{l}\text { Medical } \\
\text { oncology }\end{array}$ & 5793.60 & 11.2 & $\begin{array}{l}\text { Gynaecology } \\
\text { \& obstetric } \\
\text { surgery }\end{array}$ & 17777.99 & 11.6 \\
\hline 3 & $\begin{array}{l}\text { Genitourinary } \\
\text { surgery }\end{array}$ & 22317.91 & 8.3 & ENT & 11157.22 & 8.2 \\
\hline 4 & ENT & 11157.22 & 8.2 & Nephrology & 8320.72 & 7.5 \\
\hline 5 & $\begin{array}{l}\text { Cardiothoracic } \\
\text { surgeries }\end{array}$ & 79584.38 & 6.2 & $\begin{array}{l}\text { Radiation } \\
\text { oncology }\end{array}$ & 20051.16 & 6.3 \\
\hline
\end{tabular}

The top five specialities from among all male and all female claims have been listed in the Table 5 below. To determine if any particular specialty most utilised by men had a very high claim value (which then could explain the higher share of resource allocation to men seen in Figure 3), the average claim of each specialty is also listed alongside.

Most of the male claims came from the specialties of nephrology, medical oncology, and ENT. Though cardiothoracic surgeries were the fifth most reported specialty for male claims, the average claim amount (INR 79584.38) was higher than all the four categories. However, this specialty was the eighth most reported specialty for women. Medical oncology had the lowest average claim value (INR 5793.60) and was the most reported (20.3\%) specialty for women's claims. The gender differences in distribution across specialty and its associated claim value may to some extent account for the gender differences in total claim reimbursed.

\section{DISCUSSION}

This paper is one of the few independent research studies based on the administrative data of CMCHIS implemented in Tamil Nadu spanning three years- 2012, 2013 and 2014. Using claims as a proxy for utilization of scheme and by drawing a $25 \%$ random sample from a larger volume of more than nine lakh cases, the analyses of the CMCHIS data has revealed stark gender differences in all the parameters explored- number of beneficiaries, claim status, average claim value, average final approved amount, total claim value and in the types of procedures and specialty. The gender differences in each category were further found to be statistically significant. Women constituted only $36.3 \%$ of all beneficiaries and a more disturbingly their share was reducing over the years. While men received an average reimbursement of INR 20546.63, women received only INR 19097.1, the difference being statistically significant. The study found that men were more represented in the medical procedures than surgical procedures, and the average claim value of surgical procedures were higher than medical. 
From the total public money spent in the CMCHIS for the target group, the male beneficiaries received a larger share, almost double of what the women received together. We argue that this gender inequality translates to gender inequity in allocation of health resources with the following explanation:

- According to the NSSO findings, in TN, women have hospitalization rates higher than that of men and form a larger proportion of hospitalized individuals. Women are hospitalized not only for sex-specific conditions such as obstetric/gynaecological but cardiovascular ailments. For instance, $12 \%$ of men and $10 \%$ of women were hospitalized for cardiovascular conditions. [22] Hence the reasons for women not using $\mathrm{CMCHIS}$ for cardiovascular treatments indicates inequity.

- Women are less likely to have financial resources, autonomy, or other forms of social protection. Therefore, women are in greater need of policy enabled resources and health protection mechanisms like PFHIS. While the CMCHIS has not discriminated women from enrolling in the scheme, the study clearly points out to the contrary, whereby the benefits have failed to reach even equal number of women.

- If women were hospitalized but were not receiving protection from CMCHIS, it is likely that they were paying out of pocket for the hospitalisation services which could become catastrophic. In fact Tamil Nadu has a dominant private provider presence where the cost for a comparable treatment can sometimes be more than ten times than in public hospitals. [18] This accentuates the economic vulnerabilities of women.

- Since the inception of scheme in 2012, so far there have not been any independent investigation of the process and impact of the scheme in general, let alone, with a gender lens. [19] For instance, there is no sex disaggregated administrative data on enrolment to verify if all eligible women have been enrolled. These concerns have not yet been addressed by other evaluation studies or by the administration.

In the light of the above discussion, the observed gender differences in utilization volume and utilization value point to unjust, unnecessary, and avoidable differences within the purview of the policy.

There could be several reasons for the observed gender differences that future research might reveal. One possible reason could be lack of awareness among the women in lower income households. Another reason could be some form of systematic exclusion from enrolment due to operational issues. Another reason could be that women attempted to use but could not, due to factors related to supply side- such as the hospital not being empanelled under the scheme or a denial by the hospital authorities. It is also possible that the specific procedures the women required to undergo were not included in the $\mathrm{CMCHIS}$ package. Some of these reasons have started emerging in recent studies. [19-21]

While two other studies have also looked at the scheme administrative data $[8,9]$, this is the first study on the Tamil Nadu scheme which takes an in-depth view with a gender lens combining a large volume of data and other existing evidence.

This paper provides much-needed evidence on the possible impact of PFHIS on women's access to health care treatment and role of public policy in furthering gender equity. There is a need to carry out further research to unearth the actual causes of this inequity and undertake measures to improve women's access to crucial inpatient services.

\section{LIMITATIONS OF STUDY}

The data analysed in this paper pertains to 2012 to 2014 . A similar analysis of recent data, especially since the CMCHIS has merged with PMJAY in 2018 would be more useful. A considerable time and effort went in cleaning the raw data given by the TPA. Some important dimensions such as education, income, religion, enrolment of family members, urban or rural, etc were not captured by the agency and hence limited the analysis.

\section{CONCLUSIONS}

Though women constitute a large proportion of the informal sector as well as the poorer sections of society, their utilization patterns of PFHI schemes have not been explored, especially in the state of TN. This study revealed that even though women were seeking in-patient services and were most likely to be enrolled in CMCHIS, that they were not utilizing the $\mathrm{CMCHIS}$ for financial protection. The findings on gender differences clearly indicate inequity in utilisation of inpatient services and healthcare resource allocation. As women often lack financial independence, this trend if left unchecked can lead to distress coping encouraging a vicious of cycle of ill-health and debt or delays and denials in healthcare seeking. The recent 
COVID19 pandemic has pushed several households further into poverty while at the same time made access to healthcare treatments more crucial but challenging. If women are facing barriers to access CMCHIS as revealed in this study, they are most likely to find accessing COVID testing, treatment, and vaccinations even if these services are included in the insurance schemes.

The study gives a wake-up call to scheme administrators, healthcare managers, insurance managers, healthcare policy makers on the need to constantly monitor the scheme using disaggregated data and address gender inequity in all forms of health insurance schemes. This study stresses the need for UHC policies to make explicit provisions and monitoring mechanisms to ensure gender equity.

\section{References}

1. Friedman EA, Gostin LO, Kavanagh MM, Periago MR, Marmot M, Coates A, et al. Putting health equity at heart of universal coverage-the need for national programmes of action. BMJ. 2019;

2. Mooney $G$. Vertical equity in health care resource allocation. Heal Care Anal. 2000;8(3):203-15.

3. Pulkki-Brannstrom A-M, Pace N, Osrin D, Bapat U, Das S, Skordis-Worrall J, et al. Maternal and neonatal health expenditure in mumbai slums (India): A cross sectional study. BMC Public Health. 2011;11(1).

4. Saikia N, Moradhvaj, Bora JK. Gender difference in health-care expenditure: Evidence from India human development survey. PLoS One. 2016;11 (7):1-15.

5. Ranjan A, Adithyan G, Parmar D. Gender Equity as a Dimension of Progress Towards Universal Health Coverage Evidence from India 's 71 st Round National Sample Survey. ESSH. 2014;

6. Bonu S, Bhushan I, Peters DH. Incidence, intensity, and correlates of catastrophic out-of-pocket health payments in India. ERD Working Paper Series. 2007. p. $1-32$.

7. Rao M, Singh PV, Katyal A, Samarth A, Bergkvist S, Renton A, et al. Has the Rajiv Aarogyasri community health insurance scheme of Andhra Pradesh addressed the educational divide in accessing health care? PLoS One. 2016;11(1):1-15.

8. Shaikh M, Peters SAE, Woodward M, Norton R, Jha V. Sex differences in utilisation of hospital care in a statesponsored health insurance programme providing access to free services in South India. BMJ Glob Heal. 2018;3(3).

9. Wagle S, Shah N. Government Funded Health Insurance Scheme in Maharashtra : Study of Rajiv Gandhi Jeevandayee Aarogya Yojana. 2017. 1-157 p.

10. Rent P, Ghosh S. Understanding the "Cash-Less" Nature of Government-Sponsored Health Insurance Schemes: Evidence From Rajiv Gandhi Jeevandayee Aarogya Yojana in Mumbai. SAGE Open. 2015;5(4).

11. Vijay G. The Business of Health Care and the Challenge of Health Security: The Case of Aarogyasri Health Insurance Programme in Andhra Pradesh. Long Road to Soc Secur OUP, New Delhi. 2012;

12. Cerceau S. Gender equality in access to health care: The role of social health protection: A case study on India's national health insurance scheme RSBY. GIZ Discuss Pap Soc Prot [Internet]. 2012; Available from: https://www.giz.de/fachexpertise/downloads/giz2012en-gender-equality-in-access-to-health-care.pdf

13. Devadasan N, Seshadri T, Trivedi M, Criel B. Promoting universal financial protection: Evidence from the Rashtriya Swasthya Bima Yojana (RSBY) in Gujarat, India. Heal Res Policy Syst. 2013;1 1 (1):1-8.

14. Grover S, Palacios R. The first two years of RSBY in Delhi. India's Heal Insur Scheme Poor Evid from Early Exp Rashtriya Swasthya Bima Yojana New Delhi Cent Policy Res. 2011;153-88.

15. Ministry of Statistics and Programme Implementation. Health in India (NSS 71st round). 2016;

16. Ramprakash R, Lingam L. Publicly Funded Health Insurance Schemes (PFHIS): A Systematic and Interpretive Review of Studies Does Gender Equity Matter? eSSH. 2018;

17. Chhabra S, Smith O, Tandon A, Ulep V. Nuts and Bolts of the Chief Minister's Comprehensive Health Insurance Scheme (CMCHIS): A Case Study from Tamil Nadu World Bank Team [Internet]. 2019. Available from: www.worldbank.org

18. Karan AK, Srivastava S, Chakraborty A, Matela H, Vaidyanathan $G$, Muraleedharan V, et al. Key Indicators of Morbidity, Utilization and Health Expenditure - Tamil Nadu. 2016;(October):1-77.

19. RamPrakash $R$, Lingam $L$. Why is women's utilization of a publicly funded health insurance low?: a qualitative study in Tamil Nadu, India. BMC Public Health. $2021 ; 21(1)$. 
20. Karpagam S, Vasan A, Seethappa V. Falling Through the Gaps: Women Accessing Care under Health Insurance Schemes in Karnataka. Indian J Gend Stud. 2016;23(1):69-86.

21. Nandi S, Dasgupta R, Garg S, Sinha D, Sahu S, Mahobe R. Uncovering Coverage: Utilisation of the Universal Health Insurance Scheme, Chhattisgarh by Women in Slums of Raipur. Indian J Gend Stud. 2016;23(1):43-68.

22. RamPrakash R. Gender Analysis of Publicly Funded Health Insurance Schemes: A study of Chief Minister's Comprehensive Health Insurance Scheme of Tamil Nadu. Doctoral thesis. 2018. Tata Institute of Social Sciences. Hyderabad. 
TABLE 6: GENDER DIFFERENCES IN UTILISATION OF CMCHIS 2012-2014

\begin{tabular}{|l|l|l|l|}
\hline & $\begin{array}{l}\text { PATIENT } \\
\text { GENDER }\end{array}$ & TOTAL \\
\hline & Male & Female & \\
\hline 2012 & 33303 & 22446 & 55749 \\
\hline & $\mathbf{5 9 . 7 0 \%}$ & $\mathbf{4 0 . 3 0 \%}$ & $100.00 \%$ \\
\hline 2013 & 54520 & 31284 & 85804 \\
\hline & $63.50 \%$ & $36.50 \%$ & $100.00 \%$ \\
\hline & 58776 & 29934 & 88710 \\
\hline & $66.30 \%$ & $33.70 \%$ & $100.00 \%$ \\
\hline & 146599 & 83664 & 230263 \\
\hline & $63.70 \%$ & $36.30 \%$ & $100.00 \%$ \\
\hline
\end{tabular}

\begin{tabular}{|l|l|l|l|}
\hline & VALUE & DF & $\begin{array}{l}\text { ASYMP. SIG. (2- } \\
\text { SIDED) }\end{array}$ \\
\hline Pearson Chi-Square & 629.859 a & 2 & 0 \\
\hline Likelihood Ratio & 627.422 & 2 & 0 \\
\hline Linear-by-Linear Association & 623.126 & 1 & 0 \\
\hline $\begin{array}{l}\text { N of Valid Cases } \\
\text { a 0 cells (0.0\%) have expected } \\
\text { count less than 5. The minimum } \\
\text { expected count is 20255.90. }\end{array}$ & 230263 & & \\
\hline
\end{tabular}

TABLE 7: CLAIM STATUS IN CMCHIS BY GENDER_2012-14

\begin{tabular}{|l|l|l|l|}
\hline & VALUE & DF & ASYMP. SIG. (2-SIDED) \\
\hline $\begin{array}{l}\text { Pearson Chi- } \\
\text { Square }\end{array}$ & $14.785 \mathrm{a}$ & 2 & 0.001 \\
\hline Likelihood Ratio & 15.053 & 2 & 0.001 \\
\hline N of Valid Cases & 230265 & & \\
\hline $\begin{array}{l}\text { a } 0 \text { cells (0.0\%) have expected count less than 5. The minimum expected count is } \\
\text { 334.27. }\end{array}$
\end{tabular}


TABLE 8: GENDER DIFFERENCES IN CLAIMED AND FINAL APPROVED VALUE IN CMCHIS_2012 TO 14 - T TEST RESULTS

\begin{tabular}{|c|c|c|c|c|c|c|c|c|c|}
\hline & \multicolumn{5}{|c|}{ Levene's Test for Equality of Variances } & & \multirow[b]{2}{*}{$\begin{array}{l}\text { Std. Error } \\
\text { Difference }\end{array}$} & \multirow[b]{2}{*}{$\begin{array}{l}99 \% \\
\text { Confidence } \\
\text { Interval of } \\
\text { the } \\
\text { Difference }\end{array}$} & \\
\hline & $\mathrm{F}$ & Sig. & $\mathrm{T}$ & df & $\begin{array}{l}\text { Sig. (2 } \\
\text { tailed) }\end{array}$ & $\begin{array}{l}\text { Mean } \\
\text { Difference }\end{array}$ & & & \\
\hline & & & & & & & & Lower & Upper \\
\hline \multirow[t]{2}{*}{$\begin{array}{l}\text { Claimed } \\
\text { Amount in } \\
\text { INR }\end{array}$} & 317.52 & 0 & 18.236 & 230262 & 0 & 1418.454 & 77.785 & 1218.092 & 1618.815 \\
\hline & & & 18.629 & 185444 & 0 & 1418.454 & 76.143 & 1222.32 & 1614.587 \\
\hline $\begin{array}{l}\text { Final } \\
\text { Approval } \\
\text { Amount in } \\
\text { INR }\end{array}$ & 217.76 & 0 & 15.188 & 228617 & 0 & 1449.528 & 95.44 & 1203.689 & 1695.366 \\
\hline 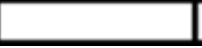 & & & 15.397 & 180169 & 0 & 1449.528 & 94.146 & 1207.022 & 1692.034 \\
\hline
\end{tabular}

TABLE 9: GENDER DIFFERENCES IN CMCHIS UTILIZATION ACROSS SPECIALTY 2012-2014

\begin{tabular}{|l|l|l|l|}
\hline & VALUE & DF & $\begin{array}{l}\text { ASYMP. SIG. (2- } \\
\text { SIDED) }\end{array}$ \\
\hline Pearson Chi-Square & $171.200 \mathrm{a}$ & 2 & 0 \\
\hline Likelihood Ratio & 171.912 & 2 & 0 \\
\hline $\begin{array}{l}\text { N of Valid Cases } \\
\begin{array}{l}\text { a O cells (0.0\%) have } \\
\text { The minimum expected count less than } 5 . \\
\text { count is 190.39. }\end{array}\end{array}$ & 230265 & & \\
\hline
\end{tabular}

